\title{
Biochemical Quality Indicators and Enzymatic Activity of Wheat Flour from the Aspect of Climatic Conditions
}

\author{
Jelena Tomić $\mathbb{D D}^{1},{ }^{1}$ Aleksandra Torbica $\mathbb{D D}^{1},{ }^{1}$ Miona Belović, ${ }^{1}$ \\ Ljiljana Popović, ${ }^{2}$ and Nada Knežević ${ }^{3}$ \\ ${ }^{1}$ Institute of Food Technology, University of Novi Sad, Bulevar cara Lazara 1, 21000 Novi Sad, Serbia \\ ${ }^{2}$ Faculty of Technology, University of Novi Sad, Bulevar cara Lazara 1, 21000 Novi Sad, Serbia \\ ${ }^{3}$ Podravka d.d., Ante Starčevića 32, 48000 Koprivnica, Croatia \\ Correspondence should be addressed to Jelena Tomić; jelena.tomic@fins.uns.ac.rs
}

Received 30 October 2017; Accepted 29 January 2018; Published 28 February 2018

Academic Editor: Giuseppe Zeppa

Copyright (C) 2018 Jelena Tomić et al. This is an open access article distributed under the Creative Commons Attribution License, which permits unrestricted use, distribution, and reproduction in any medium, provided the original work is properly cited.

\begin{abstract}
The contents of free sulphydryl groups (SH), disulphide bonds (SS), and free amino groups $\left(\mathrm{NH}_{2}\right)$ were determined in order to estimate the extent of climatic condition influence on gluten quality. The analysis included four bread wheat varieties grown in two production years (2011 and 2012) with different climatic conditions in different locations. According to our previously reported results, the working hypothesis was that enzyme activity for breadmaking purpose was insufficient. The aim of this paper was to study the influence of naturally present enzymes on the bread quality by the addition of previously extracted and freeze-dried albumins to the base flour as an additive. The selection of samples was made on the basis of different combinations of proteolytic and $\alpha$-amylolytic enzymes activity levels. For samples from 2012 production year, the content of SH groups was significantly higher. Regarding the SS content, the obtained results exhibited the opposite trend. Variations in $\mathrm{NH}_{2}$ content were dominantly caused by temperature treatment of tested samples. The addition of freeze-dried albumins to bread improved its specific volume in a lesser extent, while bread crumb texture was significantly improved.
\end{abstract}

\section{Introduction}

The key issue of automatic processing in bakery industry is supply of wheat flour of uniform quality, which is nowadays very difficult to achieve considering the altered climatic conditions. The optimization of existing technological process is often applied as an alternative. As a response to the unfavourable climatic conditions, the changes occur on different grain components and in different extent. Therefore it is very important to know the extent of those changes and relationships among grain components.

The main goal of numerous studies related to the investigation of altered climatic conditions on wheat flour quality was testing of gluten proteins as the main functional components that define the technological quality of wheat flour. Gluten storage proteins are composed of the monomeric gliadins and high and low molecular weight glutenin subunits (HMW-GS and LMW-GS). Formation of gluten network during mixing is enabled through inter- and intramolecular cross linking within monomeric gliadin fractions and within and between glutenin polymers, formed as a consequence of interchange reactions between sulphydryl groups $(\mathrm{SH})$ and disulphide bonds (SS) $[1,2]$. Although disulphide bonds are present in both gluten components, it is considered that only the intra- and interchain disulphide bonds among glutenins are responsible for their association within the glutenin macropolymer and the subsequent function and structure of gluten [3]. Therefore it could be concluded that sulphydryl group and disulphide bond content affect dough rheological properties and baking performance [4].

High temperature can significantly impact gluten quantity and the percentage of gliadins and glutenins, but gliadins are more susceptible to the influence of climatic conditions than glutenins [5]. Varying the duration and time of wheat exposure to heat stress at the filling stage, Castro et al. [6] found that high temperatures reduce duration of the filling 
stage of grain. It has been proven that the time and speed of glutenin polymerization, as well as the time of exposure to heat stress during wheat development, can be the key factors in explaining the effect of heat stress on wheat functionality [7]. In that case, the accumulation of albumins and globulins is shifted from those proteins active in biosynthesis and metabolism to those with roles in storage and protection against biotic and abiotic stresses [8]. Taking into account the complexity of changes that occur as a result of altered protein synthesis due to unfavourable climatic conditions, the aim of this paper is to examine the biochemical condition of flour from the two production years. Justification for this kind of investigation leans on the fact that fluctuation of wheat quality has a tendency to become a frequent problem. For that purpose, the content of free sulphydryl groups $(\mathrm{SH})$, disulphide bonds (SS), and free amino groups $\left(\mathrm{NH}_{2}\right)$ as indicators of gluten quality was determined.

Based on the analysed literature data, it can be concluded that the studies defining certain protein components as well as biochemical indicators do not indicate a clear connection between individual constituents of wheat flour and its technological quality. In terms of testing the effects of albumin on flour quality, there are studies in which dough is subjected to commercial enzymes, so we can conclude their effect when they are added to the flour. However, we do not possess any knowledge of the effects of albumin in real systems. In order to study the influence of naturally present enzymes on the bread quality, albumins were extracted, freeze-dried, and added to the base flour as an additive. This approach has not been used before, to the best of our knowledge. Additional experiment presented in this paper represents the continuation of previous research, in which albumins profile, proteolytic and $\alpha$-amylolytic activity level, and baking performance of wheat varieties from two production years were examined [9]. The results of proteolytic and $\alpha$-amylolytic activity published in that paper served as a tool for the choice of wheat samples studied in the additional experiment.

\section{Materials and Methods}

2.1. Materials. Examinations were carried out on four common wheat (Triticum aestivum L.) varieties (Pobeda (Pob), Zvezdana (Zve), Gordana (Gord), and Apache (Ap)), grown in two production years (2011 and 2012) in four locations (I, II, III, and IV) in Northern Serbia. Pobeda (standard for wheat quality in Serbia) and Zvezdana and Gordana (Serbian varieties developed in the last decade) were bred by the Institute of Field and Vegetable Crops, Novi Sad, Serbia, whereas Apache (the most cultivated variety in France and widespread in Serbia) was bred by Limagrain, Chappes, France. The measurements of temperature and precipitation at meteorological stations in two production years and selected locations were observed from the beginning of May until the time of harvest (July). Heat stress was characteristic of both production years. For 2011 production year, maximum daily temperatures (for the May and July) were above $31^{\circ} \mathrm{C}$ and $38^{\circ} \mathrm{C}$, respectively. The number of days with maximum temperatures above $30^{\circ} \mathrm{C}$ across the tested locations ranged from 12 to 26 . However, in 2012, maximum temperatures exceeded $35^{\circ} \mathrm{C}$ and the number of days with maximum temperatures above $30^{\circ} \mathrm{C}$ was markedly higher (from 31 to 41).

2.2. Milling. The wheat samples were milled using a Bühler MLU 202 mill (Bühler, Uzwil, Switzerland).

2.3. $\alpha$-Amylase Activity. $\alpha$-Amylase activity (Ceralpha U/g) of flour was determined using the Ceralpha method (Megazyme International, Wicklow, Ireland) intended for the determination of plant and microbial alpha-amylases. At least three replicates were performed for each analysis.

2.4. Proteolytic Activity. Proteolytic activity of wheat flour was determined as described by Tomić et al. [9].

2.5. Free Sulphydryl and Disulphide Groups Content. Contents of thiol ( $\mathrm{SH}$ ), thiol equivalent (SHeq), and disulphide (SS) groups from samples were assayed according to the procedure described by Morel et al. [10] with some modifications. For $\mathrm{SH}$ determination, $0.18 \mathrm{~g}$ of ground sample was mixed for $15 \mathrm{~min}$ with $3.9 \mathrm{~mL}$ of propan-2-ol, Tris/ $\mathrm{HCl}$ buffer (250 mM, pH 8.5), and 5,5'-dithiobis-2-nitrobenzoic acid (DNTB) $(4 \mathrm{~g} / \mathrm{L}$, in ethanol) solution $(1 / 1 / 0.2, \mathrm{v} / \mathrm{v} / \mathrm{v})$. After centrifugation, absorbance of the nitrothiobenzoate anion was read at $412 \mathrm{~nm}$. Regarding the determination of the content of disulphide bonds, the sample was reduced and washed with dithioerythritol (DTE) $(40 \mathrm{mM}$ in $80 \mathrm{mM}$ Tris/ $\mathrm{HCl} \mathrm{pH} \mathrm{8.5,0.3} \mathrm{mL)} \mathrm{and} \mathrm{glacial} \mathrm{acetone} \mathrm{(including}$ $100 \mathrm{mM}$ acetic acid) to determine thiol equivalent groups. The obtained pellet was suspended in $0.87 \mathrm{~mL}$ of DNTB/propan2-ol solution, vortexed, and then centrifuged for $15 \mathrm{~min}$. Absorbance was read at $412 \mathrm{~nm}$. Disulphide (SS) group content was calculated from SH and Sheq determinations.

2.6. Free Amino Groups Content. The content of free amino groups was determined according to the procedure described by Pérez et al. [3] from wet gluten washed out from flour samples according to standard ICC method 155 [11]. Before determination of free amino groups, the wet gluten samples were incubated at two different temperatures, $30^{\circ} \mathrm{C}$ and $37^{\circ} \mathrm{C}$, for three hours. These temperatures were selected in order to imitate the dough processing conditions $\left(30^{\circ} \mathrm{C}\right)$ and to provide optimal conditions for the activity of potentially present enzymes $\left(37^{\circ} \mathrm{C}\right)$ [12]. The content of free $\mathrm{NH}_{2}$ groups from incubated samples was compared with the free $\mathrm{NH}_{2}$ content of the control sample, determined immediately after gluten washing without previous incubation. The determination of free amino groups was carried out in four replicates, where the results were calculated against a serine standard curve. The spectrophotometric readings were performed at $340 \mathrm{~nm}$.

2.7. Bread Preparation. Baking trials were conducted in laboratory conditions. All ingredients (300 $\mathrm{g}$ of flour $(14 \mathrm{~g} / 100 \mathrm{~g}$ moisture basis), $2 \%$ of fresh yeast on flour basis, and $2 \%$ of salt on flour basis) were mixed in a high-speed Diosna mixer (Dierks\&Söhne, Maschinenfabrik, Osnabrück, Germany) for $5 \mathrm{~min}$. Water addition required for reaching the dough consistency of $400 \mathrm{BU}$ was calculated on the basis of farinogram water absorption and the degree of softening [13]. 


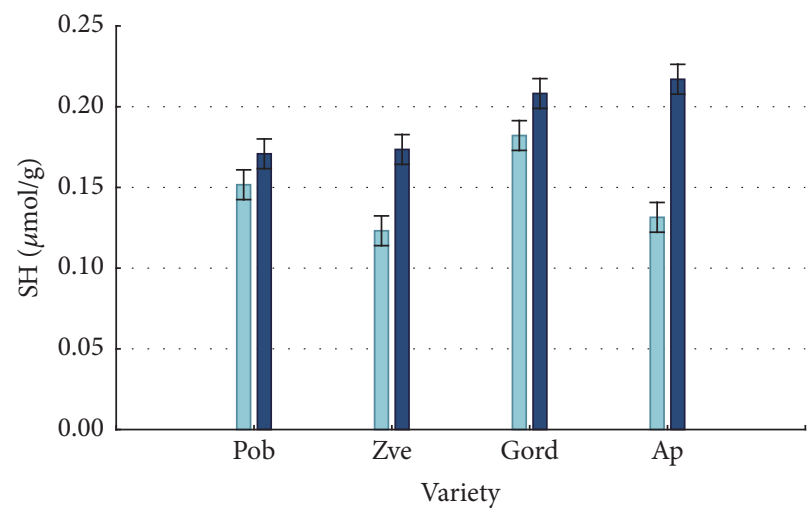

2011
2012

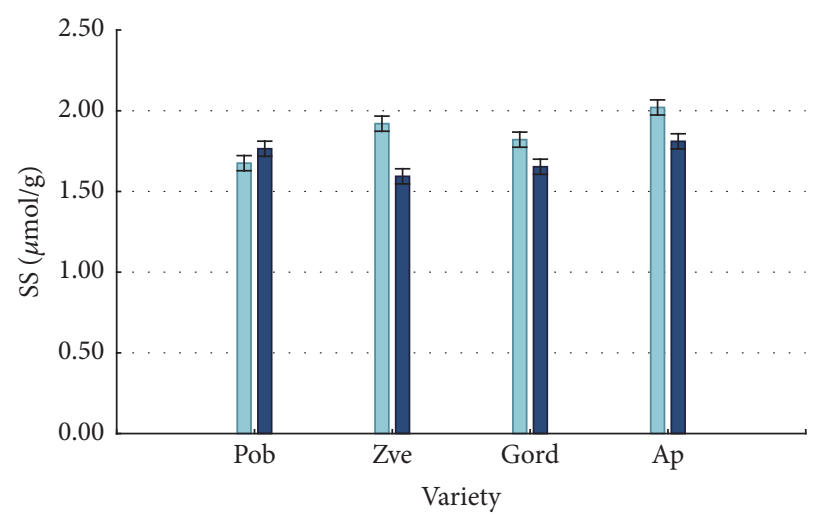

2011

2012

(a)

(b)

FIGURE 1: The influence of production year and variety on the content of free sulfhydryl groups (a) and disulphide bonds (b). Vertical bars denote 0.95 confidence intervals.

After mixing, dough was fermented for $120 \mathrm{~min}$ at $30^{\circ} \mathrm{C}$ and $75 \%$ relative humidity $(\mathrm{RH})$. Punching down was carried out after 60 and $90 \mathrm{~min}$ of fermentation. After dividing (130 g), hand-moulding, and final proofing for another $70 \mathrm{~min}$ at $30^{\circ} \mathrm{C}$ and $75 \% \mathrm{RH}$, doughs were baked at $220^{\circ} \mathrm{C}$ for $15 \mathrm{~min}$. The breads were cooled at room temperature for $1 \mathrm{~h}$ and stored in a climate chamber for $23 \mathrm{~h}$ at controlled temperature conditions $\left(22 \pm 0.7^{\circ} \mathrm{C}\right)$ and humidity $(75 \pm 0.5 \%)$.

In order to examine the effect of increased quantity of enzymes on a specific indicator of bread quality-specific bread volume-extraction of albumins from selected wheat flour samples was performed. The selection of samples was based on different combinations of proteolytic and $\alpha$ amylolytic activity levels. Wheat flour $(600 \mathrm{~g})$ was extracted with $3000 \mathrm{ml}$ of deionized water, with intensive homogenization for $2 \mathrm{~h}$. The resulting extracts were centrifuged at 3,000 rpm for $10 \mathrm{~min}$. The obtained supernatant, which represents an albumin fraction, was prepared for freezedrying process in the form of plate blocks with height up to $1 \mathrm{~cm}$. The freeze-drying process was carried out in a pilot chamber where temperature ranged from $-30^{\circ} \mathrm{C}$ to $43.3^{\circ} \mathrm{C}$ for $10 \mathrm{~h}$. The dried samples were packed in plastic bags under inert atmosphere (nitrogen). Freeze-dried albumins were added to $200 \mathrm{~g}$ of base wheat flour.

2.8. Bread Specific Volume. The breads were weighed after the cooling and their volume was determined by millet displacement method. The specific volume $\left(\mathrm{cm}^{3} / \mathrm{g}\right)$ was calculated as a ratio of loaf volume/bread weight.

2.9. Texture Measurements. The analysis of texture was carried out $24 \mathrm{~h}$ after baking using the TA.XT2 Texture Analyser (Stable Micro Systems, UK) with a $30 \mathrm{~kg}$ load cell. Texture profile analysis (TPA) was conducted using a P/75 (75 mm diameter) aluminium compression cylinder. Samples from the centre of the crumb slices were cut into cylinders (35 mm diameter, $12.5 \mathrm{~mm}$ thick) and compressed. Force and height calibration of the instrument was done prior to measurements to minimize error. TPA settings were as follows: pretest speed $=1 \mathrm{~mm} / \mathrm{s}$; test and posttest speed $=$ $5 \mathrm{~mm} / \mathrm{s}$; deformation $=75 \%$; and wait time between first and second compression cycles $=5 \mathrm{~s}$. The measured parameters were hardness, cohesiveness, springiness, chewiness, and resilience. The tests were performed in triplicate.

2.10. Colour Measurement. Colour measurement of bread crust and crumb was performed by Chroma Meter CR-400 (Konica Minolta Co., Ltd., Osaka, Japan) in five replications on two samples per batch. CIE $L^{*}$ (lightness), CIE $a^{*}\left(+a^{*}\right.$ $=$ redness, $-a^{*}=$ greenness $)$, and $\mathrm{CIE} b^{*}\left(+b^{*}=\right.$ yellowness, $-b^{*}=$ blueness) were read using a D65 light source and the observer angle of $2^{\circ}$. The tristimulus values of CIE $L^{*} a^{*} b^{*}$ readings were calibrated against a standard white plate $(Y=$ $84.8 ; x=0.3199 ; y=0.3377)$.

2.11. Statistical Analysis. The data were statistically analysed by Statistica 13.2 software (Dell Inc., USA, 2016). The collected experimental data was analysed using the analysis of variance (ANOVA). The comparison among means was done by the LSD test which regarded significance at $P<0.05$.

\section{Results and Discussion}

3.1. Free Sulphydryl and Disulphide Groups Content. The values of free sulphydryl and disulphide groups content are presented in Figures 1(a) and 1(b). Differences in the free sulphydryl group content are mostly influenced by variety and production year, while, in the case of disulphide bonds, the variability of the obtained results is mostly contributed by production year as well as by interaction between production year and location (data not shown). The content of free sulphydryl groups for 2012 was significantly higher $(0.14-0.26 \mu \mathrm{mol} / \mathrm{g})$ compared to 2011 production year $(0.10-0.21 \mu \mathrm{mol} / \mathrm{g})$.

Significantly higher values of free sulphydryl groups for flour samples from 2012 production year are probably the 

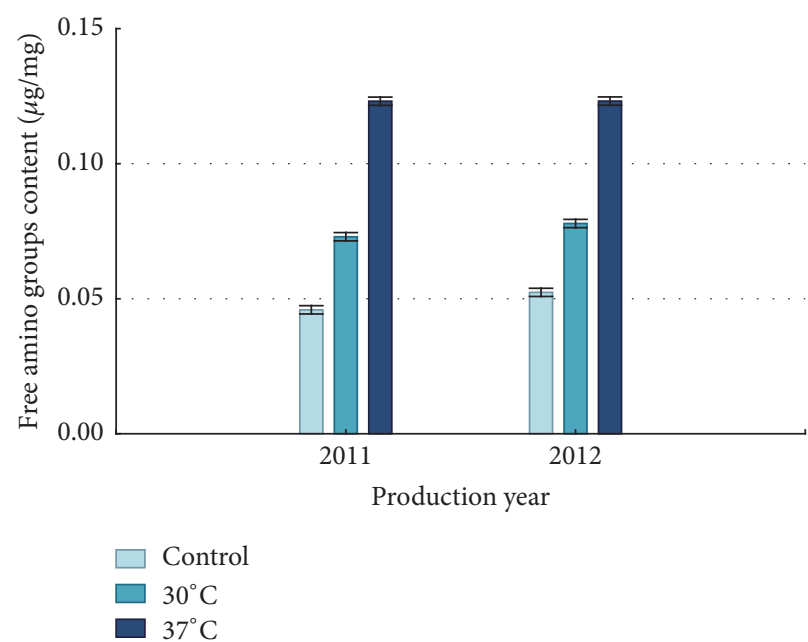

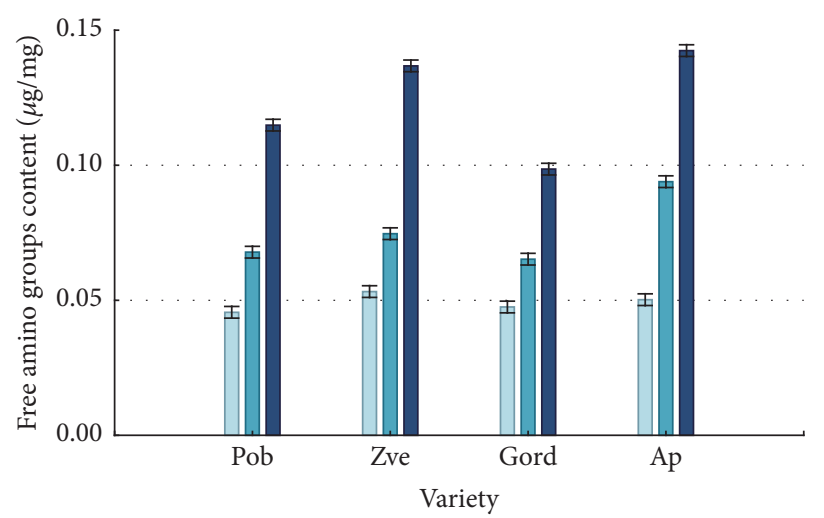

$\square$ Control
$\square 30^{\circ} \mathrm{C}$
$\square 37^{\circ} \mathrm{C}$

(a)

(b)

FIGURE 2: The influence of incubation temperature and production year (a) and variety (b) on the content of free amino groups. Vertical bars denote 0.95 confidence intervals.

consequence of unfavourable climatic conditions regarding maximum temperatures and the number of tropical days during the growing season. High temperatures cause changes in the composition and quality of proteins, which are manifested through the reduction of the glutenin polymer size $[6,7,14]$.

Although protein disulphide isomerase (PDI) is known to be a catalyst during the formation and reorganization of disulphide bonds in developing wheat grains, it could be assumed that the above-mentioned high temperatures influenced its lower activity. However, there are contradictory opinions about simultaneously occurring period of maximal PDI activity and period of S-S bonds formation in glutenin macropolymer. Some authors state that the formation of S$S$ bonds in glutenin macropolymer is related to maximal PDI activity, while the other authors state that S-S bonds formation does not coincide with its peak activity [15]. Johansson et al. [16] concluded that variation in temperature did not influence the accumulation of wheat grain proteins, indicating that availability of nutrients, for example, nitrogen and sulphur, is the more important factor in determining the amount and size distribution of polymeric proteins [16]. However, taking into account the fact that the temperatures during the grain filling in our study were higher than in study conducted by Johansson et al. [16], it could be suggested that significant increase in free sulphydryl groups results exclusively from climatic conditions.

Regarding the content of disulphide bonds, significantly higher content was recorded for the 2011 production year $(1.33-2.59 \mu \mathrm{mol} / \mathrm{g})$, as the content of disulphide bonds indicates the quality of gluten; that is, higher content of disulphide bonds corresponds to better rheological properties of gluten [17].

3.2. Free Amino Groups Content. By examination of the simultaneous influence of all examined factors as well as the influence of individual factors (production year, variety, location, and gluten incubation temperature) on the content of free amino groups $\left(\mathrm{NH}_{2}\right)$, it could be noticed that the variability of this parameter was mostly affected by gluten incubation temperature. The average content of free $\mathrm{NH}_{2}$ groups showed the same trend in both production years, that is, amino groups content increase along with the increase of gluten incubation temperature (Figures 2(a) and 2(b)). Average values at $37^{\circ} \mathrm{C}$ from both years are at the same level. Since the content of free $\mathrm{NH}_{2}$ groups represents an indicator of proteolytic activity [18], this result implies that the different average values determined in nontreated gluten and gluten incubated at $37^{\circ} \mathrm{C}$ are not caused by the proteolytic activity of wheat enzymes. However, there are marked differences between the values in the nontreated samples and samples incubated at $30^{\circ} \mathrm{C}$ (temperature of dough kneading). These differences justify the application of both incubation regimes of gluten before the determination of free $\mathrm{NH}_{2}$ groups content, because they point to differences in the quality of wheat dough occurring in the real system.

Differences in the content of free $\mathrm{NH}_{2}$ groups that are evident among the tested varieties (Figure 2(b)) regarding all three applied treatments indicate the influence of variety on the quality of proteins. In addition, there are significant differences between the values measured at $37^{\circ} \mathrm{C}$, which indicate the different proteolytic activity of the tested wheat varieties, representing a useful data in the practice.

3.3. Characterization of Enriched Breads. In a previously published paper, obtained results suggested that enzyme activity levels were under optimum level which negatively affected the bread specific volume and were exclusively the consequence of climatic conditions [9]. To verify this presumption, the additional experiment was performed. For that purpose, the flour bread samples were chosen on the basis of different combinations of enzyme activity levels. This was done in the following way: all enzyme activity values were 


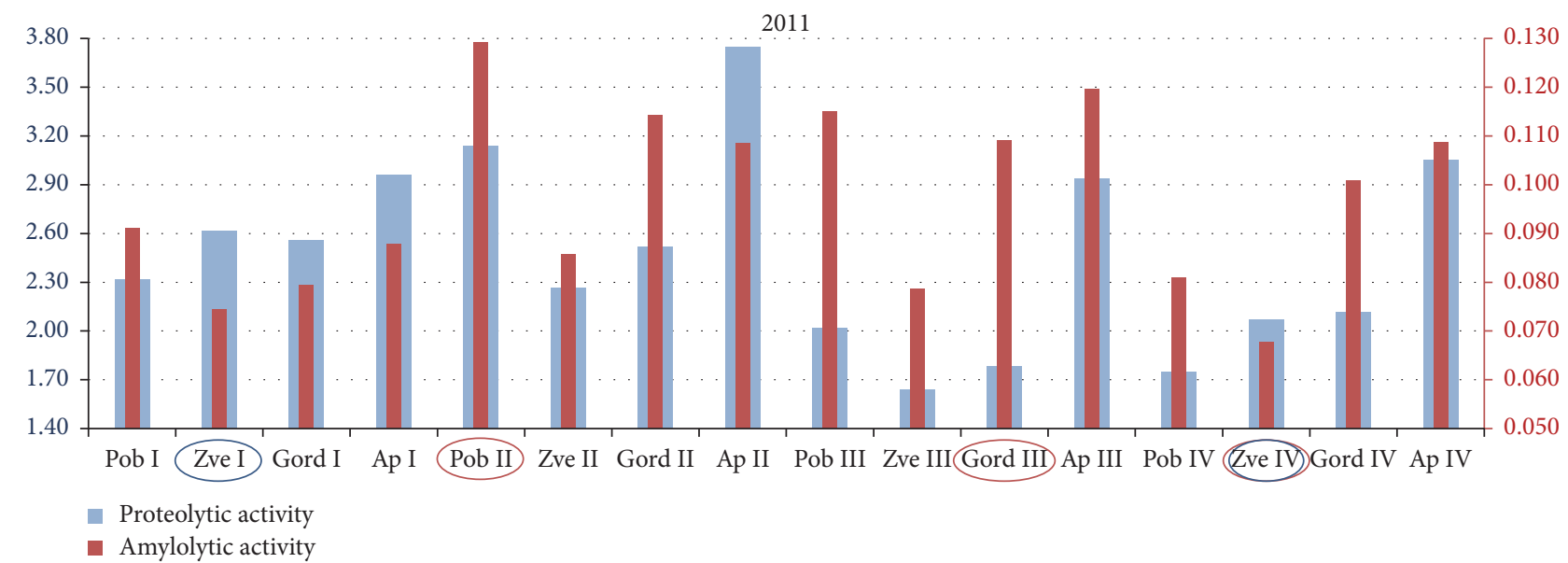

(a)

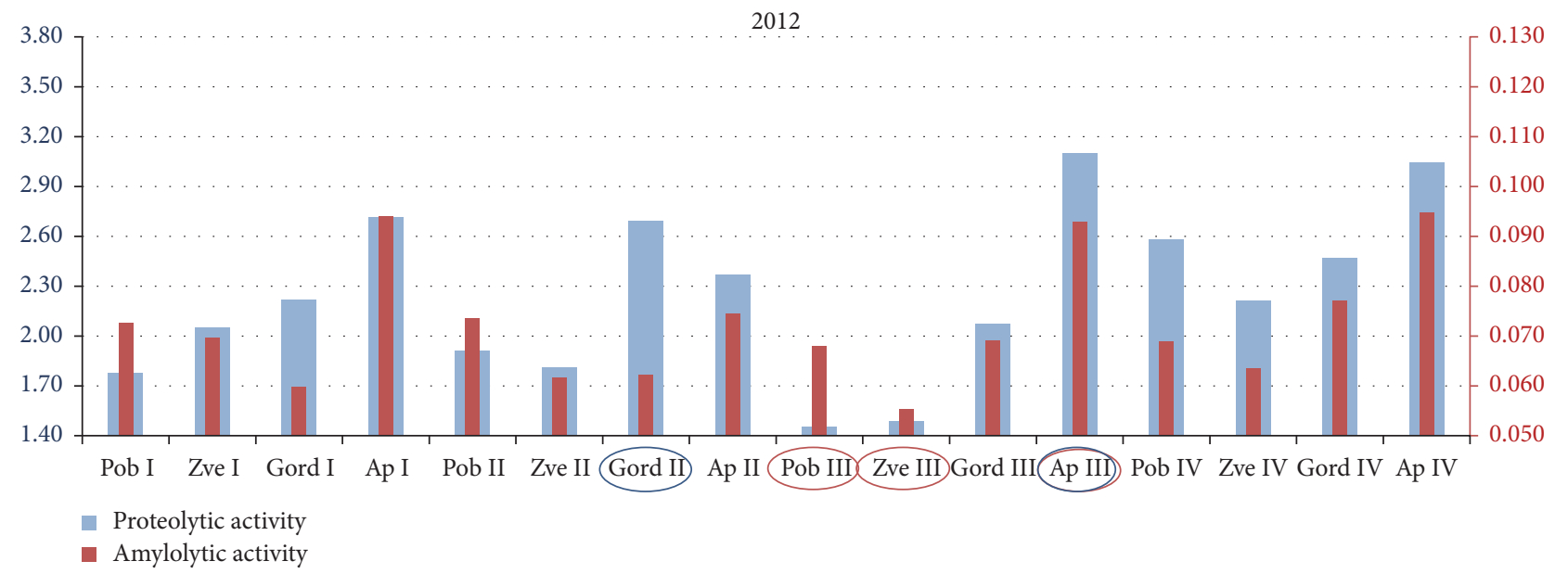

(b)

FIGURE 3: Selected samples from 2011 production year (a) and 2012 production year (b) on the basis of different levels of proteolytic and $\alpha$-amylolytic activity.

expressed as a percentage of the maximum value. The chosen samples had maximum enzyme activity, enzyme activity on the same level (approximately $50 \%$ of maximum activity), and dominant activity of one enzyme (proteolytic or amylolytic). The selected samples with corresponding values of enzyme activities are shown in Figure 3.

In order to test the effect of enzyme addition, freeze-dried albumin extracted from the wheat flour samples was added to the base flour. The process included aqueous extraction of total albumins from $600 \mathrm{~g}$ of each chosen sample, which were subsequently freeze-dried and added to $200 \mathrm{~g}$ of base flour. In this way, the initial concentration of proteolytic and $\alpha$ amylolytic enzymes in the enriched samples was theoretically increased 4 times. However, the results of Lowry method showed that the protein content of doughs with added freezedried albumins was approximately doubled (data not shown).

To define the desirable and undesirable levels of tested enzymes, we have selected the most obvious technological indicator of bread quality-specific volume of bread $\left(V_{\mathrm{sp}}\right)$. In addition, Texture Profile Analysis was carried out in order to clarify the changes in bread texture due to increased albumin content. Comparison of bread samples produced

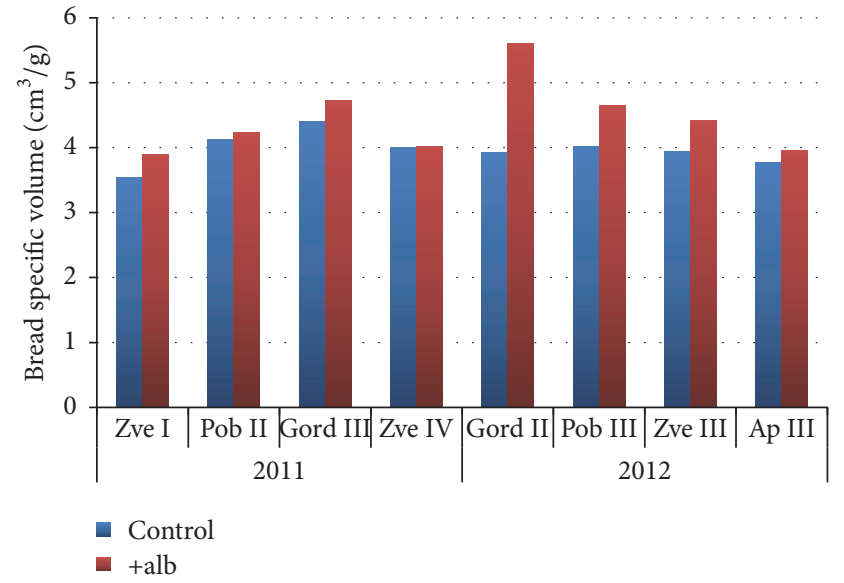

Figure 4: Comparison of specific volume of bread samples produced with increased total albumin content with control samples from both production years.

with increased total albumin content with control samples from both production years is presented in Figures 4 and 5 . 

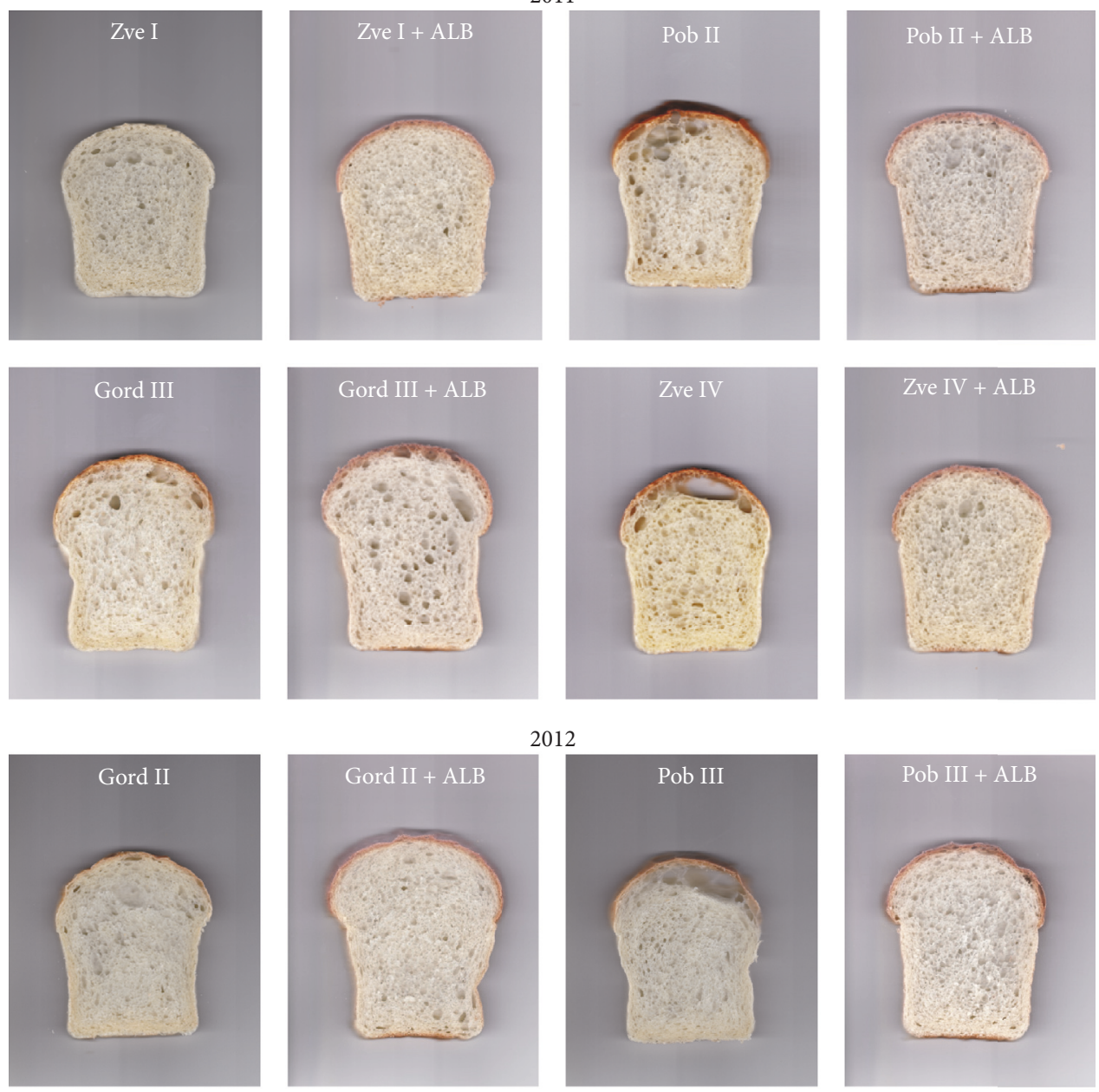

012
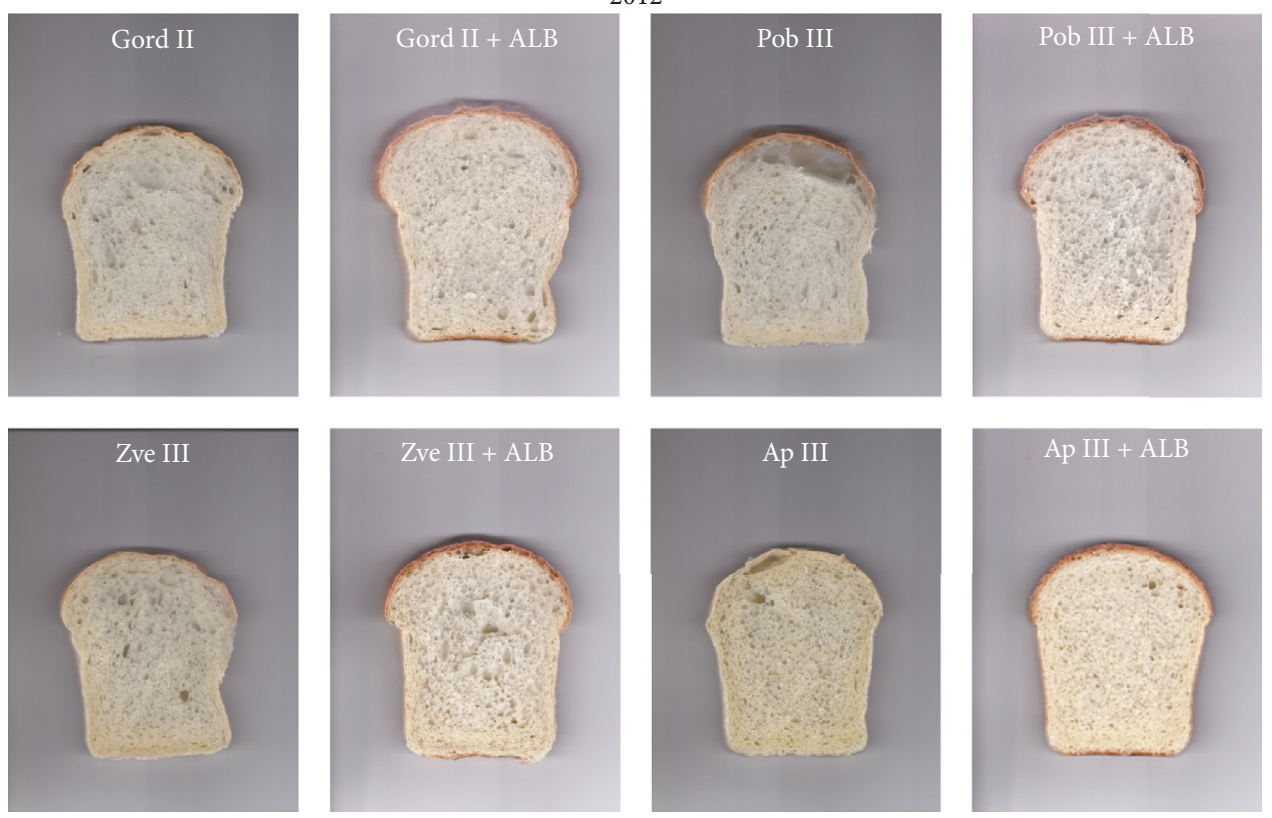

FIGURE 5: Cut loaves of bread produced with increased total albumin content and control samples from both production years.

The quality of bread with added freeze-dried albumins improved in a lesser extent in terms of specific volume increase, while bread crumb texture was significantly improved (Figure 6). The increase of bread specific volume was statistically significant in 2012 production year, contrary to small but not significant increase in 2011 production year.

Namely, both bread hardness and chewiness decreased with the addition of albumins. On the other hand, springiness and cohesiveness showed no obvious trend with bread enrichment. However, for most bread samples, resilience became lower with albumin addition, suggesting that enriched breads are less resistant to deformation. The obtained results confirmed the previous presumptions that the enzyme activity of wheat flour samples was too low and that the increase of this activity was desirable. For certain varieties, it was found that increased levels of proteolytic and amylolytic enzyme activities resulting from wheat sprouting had a positive influence on their breadmaking potential [19]. Seguchi et al. [20] reported that the addition of sprouted wheat bran in order to increase $\alpha$-amylolytic activity positively 


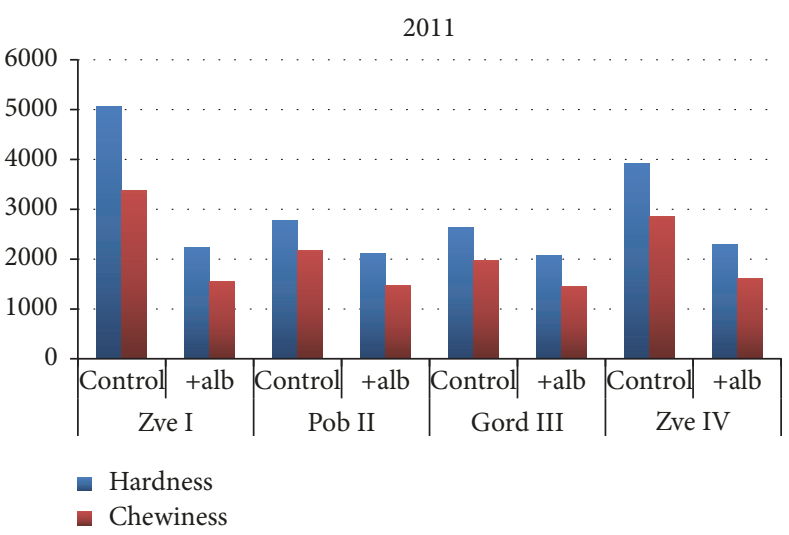

2012

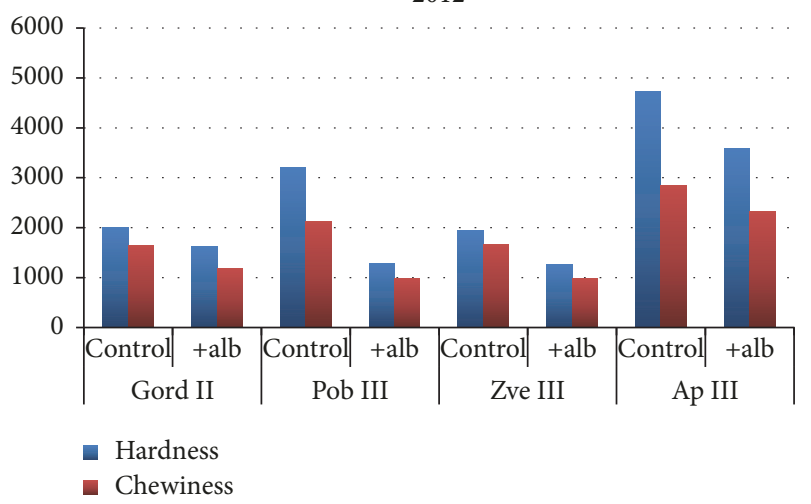

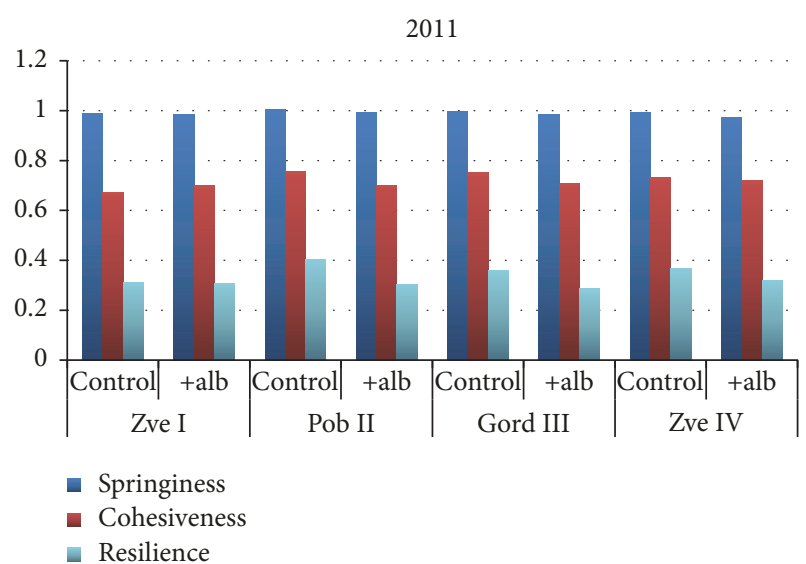

2012

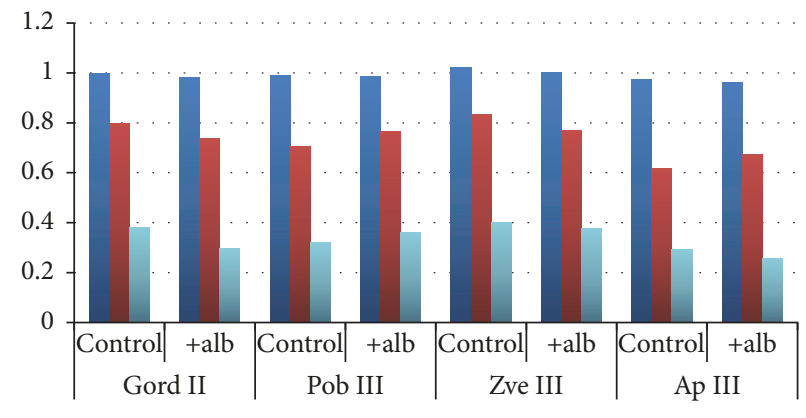

- Springiness

- Cohesiveness

- Resilience

Figure 6: Results of texture measurements obtained $24 \mathrm{~h}$ after baking for bread enriched with albumin and control bread.

affects the quality of wheat flour. Namely, the action of amylase leads to the hydrolysis of amylose and amylopectin to glucose, maltose, and oligosaccharides that are less prone to retrogradation. Hydrolysis products of low molecular weight interfere with amylopectin chains obstructing the process of their recrystallization during the bread staling. In this way, $\alpha$-amylase reduces the amount of retrogradation by modification of starch structure, which leads to the reduction of staling rate and hardness of bread crumb [21].

The colour of bread crust and crumb were measured in order to determine the changes caused by the addition of albumins (Table 1). Generally, differences between control and enriched breads were more prominent for crust colour. All bread samples with added albumin were significantly darker (lower $L^{*}$ values) and less yellow (lower $b^{*}$ values), regardless of the production year. Most bread samples had significantly more intensive red colour of crust (higher $a^{*}$ values), indicating that the addition of albumin promoted development of red tone during baking. These colour changes could be attributed to more intensive Maillard reactions during baking, leading to synthesis of amino acid-sugar reaction products (polymerized proteins and brown pigments) [22]. Regarding crumb colour, trend of darkening and shifting to more red tones due to albumin addition was not observed in all bread samples. This could be due to the fact that temperature inside bread rarely rises above $100^{\circ} \mathrm{C}$, while brown-coloured products of Maillard reactions become observable at temperatures around $105-115^{\circ} \mathrm{C}$ [23].

\section{Conclusions}

Based on sulphydryl and disulphide groups content of tested samples, it could be concluded that the values of these parameters were mainly influenced by climatic conditions. For samples from the 2012 production year, which was characterized by higher average temperatures and the number of days with daily temperatures above $30^{\circ} \mathrm{C}$, the content of $\mathrm{SH}$ groups was significantly higher. Regarding the content of disulphide bonds, significantly higher content was recorded for the 2011 production year. Variations in $\mathrm{NH}_{2}$ content were dominantly caused by temperature treatment of tested samples where significantly higher amount of $\mathrm{NH}_{2}$ groups was obtained after gluten incubation at $37^{\circ} \mathrm{C}$. The results obtained from additional experiments showed that the addition of freeze-dried albumins improved bread specific volume in a lesser extent, while bread crumb texture was significantly improved. The positive effect on bread specific volume was more prominent for the samples from 2012 production year. The obtained results showed beneficial influence of increased enzyme activities on bread final quality 
TABLE 1: The crust and crumb colour of control bread and bread enriched with albumins.

\begin{tabular}{|c|c|c|c|c|c|c|c|}
\hline \multirow{2}{*}{ Year } & \multirow{2}{*}{ Sample } & \multicolumn{3}{|c|}{ Crust } & \multicolumn{3}{|c|}{ Crumb } \\
\hline & & $L^{*}$ & $a^{*}$ & $b^{*}$ & $L^{*}$ & $a^{*}$ & $b^{*}$ \\
\hline \multirow{8}{*}{2011} & BT-Z control & $62.43^{\mathrm{a}}$ & $9.25^{b}$ & $27.41^{\mathrm{a}}$ & $77.92^{\mathrm{a}}$ & $-1.38^{\mathrm{a}}$ & $21.50^{\mathrm{a}}$ \\
\hline & BT-Z +alb & $48.14^{\mathrm{b}}$ & $15.06^{\mathrm{a}}$ & $19.16^{\mathrm{b}}$ & $77.25^{\mathrm{b}}$ & $-1.03^{\mathrm{b}}$ & $19.76^{\mathrm{b}}$ \\
\hline & SM-GD control & $53.82^{\mathrm{a}}$ & $14.19^{\mathrm{a}}$ & $31.24^{\mathrm{a}}$ & $76.46^{\mathrm{a}}$ & $-1.39^{\mathrm{b}}$ & $15.63^{\mathrm{a}}$ \\
\hline & SM-GD +alb & $44.42^{\mathrm{b}}$ & $14.30^{\mathrm{a}}$ & $15.09^{b}$ & $76.43^{\mathrm{a}}$ & $0.15^{\mathrm{a}}$ & $15.96^{\mathrm{a}}$ \\
\hline & SO-Z control & $63.96^{\mathrm{a}}$ & $9.61^{b}$ & $33.64^{\mathrm{a}}$ & $77.85^{\mathrm{a}}$ & $-1.49^{\mathrm{b}}$ & $19.58^{\mathrm{a}}$ \\
\hline & $\mathrm{SO}-\mathrm{Z}+\mathrm{alb}$ & $47.89^{\mathrm{b}}$ & $15.10^{\mathrm{a}}$ & $18.88^{\mathrm{b}}$ & $76.58^{\mathrm{b}}$ & $-0.92^{\mathrm{a}}$ & $18.26^{\mathrm{b}}$ \\
\hline & VR-P control & $50.89^{\mathrm{a}}$ & $14.12^{\mathrm{a}}$ & $28.79^{\mathrm{a}}$ & $74.66^{\mathrm{a}}$ & $-0.33^{\mathrm{b}}$ & $17.28^{\mathrm{a}}$ \\
\hline & VR-P +alb & $46.46^{\mathrm{b}}$ & $14.12^{\mathrm{a}}$ & $16.67^{\mathrm{b}}$ & $73.68^{\mathrm{a}}$ & $0.12^{\mathrm{a}}$ & $14.87^{\mathrm{b}}$ \\
\hline \multirow{8}{*}{2012} & SM-A control & $68.45^{\mathrm{a}}$ & $4.44^{\mathrm{b}}$ & $30.32^{\mathrm{a}}$ & $79.13^{\mathrm{a}}$ & $-2.03^{\mathrm{b}}$ & $22.80^{\mathrm{a}}$ \\
\hline & SM-A +alb & $42.36^{\mathrm{b}}$ & $17.38^{\mathrm{a}}$ & $22.88^{\mathrm{b}}$ & $78.90^{\mathrm{a}}$ & $-1.05^{\mathrm{a}}$ & $21.03^{\mathrm{b}}$ \\
\hline & SM-P control & $60.13^{\mathrm{a}}$ & $11.61^{\mathrm{b}}$ & $27.01^{\mathrm{a}}$ & $79.48^{\mathrm{a}}$ & $-1.37^{\mathrm{b}}$ & $14.00^{\mathrm{b}}$ \\
\hline & SM-P +alb & $39.38^{\mathrm{b}}$ & $15.64^{\mathrm{a}}$ & $19.27^{\mathrm{b}}$ & $75.89^{\mathrm{b}}$ & $-1.13^{\mathrm{a}}$ & $15.14^{\mathrm{a}}$ \\
\hline & SM-Z control & $63.13^{\mathrm{a}}$ & $9.41^{\mathrm{b}}$ & $27.30^{\mathrm{a}}$ & $79.55^{\mathrm{a}}$ & $-1.92^{b}$ & $16.79^{\mathrm{b}}$ \\
\hline & $\mathrm{SM}-\mathrm{Z}+\mathrm{alb}$ & $41.82^{\mathrm{b}}$ & $16.80^{\mathrm{a}}$ & $23.49^{\mathrm{b}}$ & $74.28^{\mathrm{b}}$ & $-1.62^{\mathrm{a}}$ & $18.30^{\mathrm{a}}$ \\
\hline & VR-GD control & $59.48^{\mathrm{a}}$ & $11.72^{\mathrm{b}}$ & $28.71^{\mathrm{a}}$ & $76.21^{\mathrm{b}}$ & $-1.59^{\mathrm{b}}$ & $16.52^{\mathrm{b}}$ \\
\hline & VR-GD +alb & $41.15^{\mathrm{b}}$ & $15.76^{\mathrm{a}}$ & $21.86^{\mathrm{b}}$ & $78.11^{\mathrm{a}}$ & $-1.02^{\mathrm{a}}$ & $16.91^{\mathrm{a}}$ \\
\hline
\end{tabular}

Data are expressed as means $(n=10)$. Values in the columns (control and +alb pairs) followed by different lowercase letters are significantly different $(P<$ $0.05)$.

confirming presumption from previously published paper [9] that tested enzyme activity levels which were under optimum level which negatively affected the bread specific volume.

\section{Conflicts of Interest}

The authors declare that there are no conflicts of interest regarding the publication of this paper.

\section{Acknowledgments}

This work was supported by the Ministry of Education, Science and Technological Development of the Republic of Serbia within the Project of Technological Development no. TR 31007 (2011-2018).

\section{References}

[1] J. A. Delcour, I. J. Joye, B. Pareyt, E. Wilderjans, K. Brijs, and B. Lagrain, "Wheat gluten functionality as a quality determinant in cereal-based food products," Annual Review of Food Science and Technology, vol. 3, no. 1, pp. 469-492, 2012.

[2] E. Johansson, A. H. Malik, A. Hussain et al., "Wheat gluten polymer structures: The impact of genotype, environment, and processing on their functionality in various applications," Cereal Chemistry, vol. 90, no. 4, pp. 367-376, 2013.

[3] G. Pérez, A. Bonet, and C. M. Rosell, "Relationship between gluten degradation by Aelia spp and Eurygaster spp and protein structure," Journal of the Science of Food and Agriculture, vol. 85, no. 7, pp. 1125-1130, 2005.

[4] H. Wieser, "Chemistry of gluten proteins," Food Microbiology, vol. 24, no. 2, pp. 115-119, 2007.

[5] D. R. Živančev, A. M. Torbica, J. M. Tomíc et al., "Effect of climate change onwheat quality andhmwglutenin subunit composition in the pannonian plain," Cereal Chemistry, vol. 93, no. 1, pp. 90-99, 2016.

[6] M. Castro, C. J. Peterson, M. Dalla Rizza et al., "Influence of heat stress on wheat grain characteristics and protein molecular weight distribution," in Wheat Production in Stressed Environments, pp. 365-371, Springer, Dordrecht, the Netherlands, 2007.

[7] S. Irmak, H. A. Naeem, G. L. Lookhart, and F. MacRitchie, "Effect of heat stress on wheat proteins during kernel development in wheat near-isogenic lines differing at Glu-D1," Journal of Cereal Science, vol. 48, no. 2, pp. 513-516, 2008.

[8] W. J. Hurkman, W. H. Vensel, C. K. Tanaka, L. Whitehand, and S. B. Altenbach, "Effect of high temperature on albumin and globulin accumulation in the endosperm proteome of the developing wheat grain," Journal of Cereal Science, vol. 49, no. 1, pp. 12-23, 2009.

[9] J. Tomić, A. Torbica, L. Popović, N. Hristov, and B. Nikolovski, "Wheat breadmaking properties in dependance on wheat enzymes status and climate conditions," Food Chemistry, vol. 199, pp. 565-572, 2016.

[10] M.-H. Morel, A. Redl, and S. Guilbert, "Mechanism of heat and shear mediated aggregation of wheat gluten protein upon mixing," Biomacromolecules, vol. 3, no. 3, pp. 488-497, 2002.

[11] ICC-Standard Method no. 155, Determination of wet gluten quantity and quality (Gluten Index ac. to Perten) of whole wheat meal and wheat flour (Triticum aestivum), 1994.

[12] A. Torbica, M. Antov, J. Mastilović, and D. Knežević, “The influence of changes in gluten complex structure on technological quality of wheat (Triticum aestivum L.)," Food Research International, vol. 40, no. 8, pp. 1038-1045, 2007.

[13] Serbian Official Methods, "Regulation of methods of physical and chemical analysis for quality control of grain, milling and bakery products, pasta and quick frozen dough," Službeni list SFRJ 74/88, Serbian Official Methods Serbia, 1988.

[14] H. A. Naeem, D. Paulon, S. Irmak, and F. MacRitchie, "Developmental and environmental effects on the assembly of glutenin 
polymers and the impact on grain quality of wheat," Journal of Cereal Science, vol. 56, no. 1, pp. 51-57, 2012.

[15] D. Every, W. B. Griffin, and P. E. Wilson, "Ascorbate oxidase, protein disulfide isomerase, ascorbic acid, dehydroascorbic acid and protein levels in developing wheat kernels and their relationship to protein disulfide bond formation," Cereal Chemistry, vol. 80, no. 1, pp. 35-39, 2003.

[16] E. Johansson, R. Kuktaite, A. Andersson, and M. L. PrietoLinde, "Protein polymer build-up during wheat grain development: Influences of temperature and nitrogen timing," Journal of the Science of Food and Agriculture, vol. 85, no. 3, pp. 473-479, 2005.

[17] J. Tomić, M. Pojić, A. Torbica et al., "Changes in the content of free sulphydryl groups during postharvest wheat and flour maturation and their influence on technological quality," Journal of Cereal Science, vol. 58, no. 3, pp. 495-501, 2013.

[18] E. J. Hajnal, J. Tomić, A. Torbica et al., "Content of free amino groups during postharvest wheat and flour maturation in relation to gluten quality," Food Chemistry, vol. 164, pp. 158165, 2014.

[19] R. A. Edwards, A. S. Ross, D. J. Mares, F. W. Ellison, and J. D. Tomlinson, "Enzymes from rain-damaged and laboratorygerminated wheat I. Effects on product quality," Journal of Cereal Science, vol. 10, no. 2, pp. 157-167, 1989.

[20] M. Seguchi, M. Uozu, H. Oneda, R. Murayama, and H. Okusu, "Effect of outer bran layers from germinated wheat grains on breadmaking properties," Cereal Chemistry, vol. 87, no. 3, pp. 231-236, 2010.

[21] I. Defloor and J. A. Delcour, "Impact of maltodextrins and antistaling enzymes on the differential scanning calorimetry staling endotherm of baked bread doughs," Journal of Agricultural and Food Chemistry, vol. 47, no. 2, pp. 737-741, 1999.

[22] I. Mohammed, A. R. Ahmed, and B. Senge, "Dough rheology and bread quality of wheat-chickpea flour blends," Industrial Crops and Products, vol. 36, no. 1, pp. 196-202, 2012.

[23] F. M. Vanin, T. Lucas, and G. Trystram, "Crust formation and its role during bread baking," Trends in Food Science \& Technology, vol. 20, no. 8, pp. 333-343, 2009. 


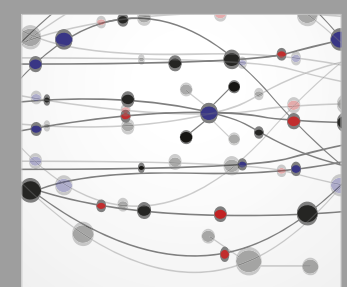

The Scientific World Journal
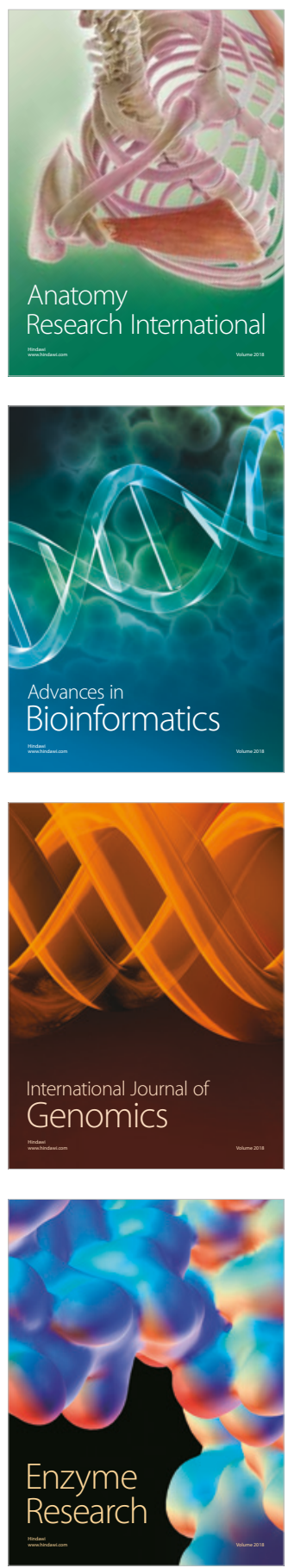
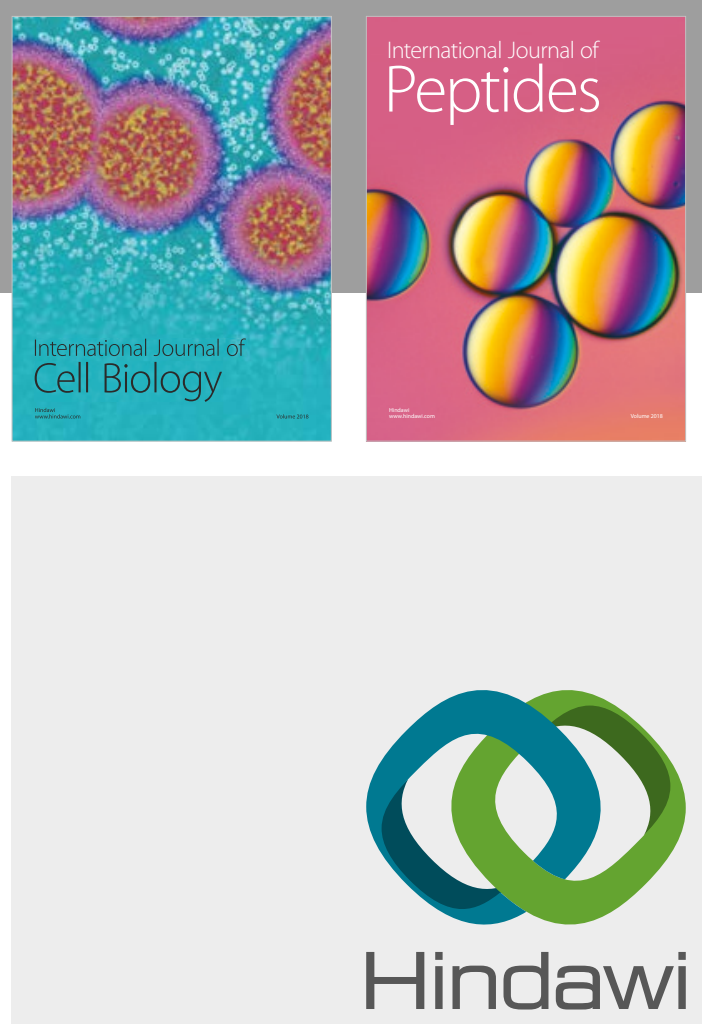

Submit your manuscripts at

www.hindawi.com
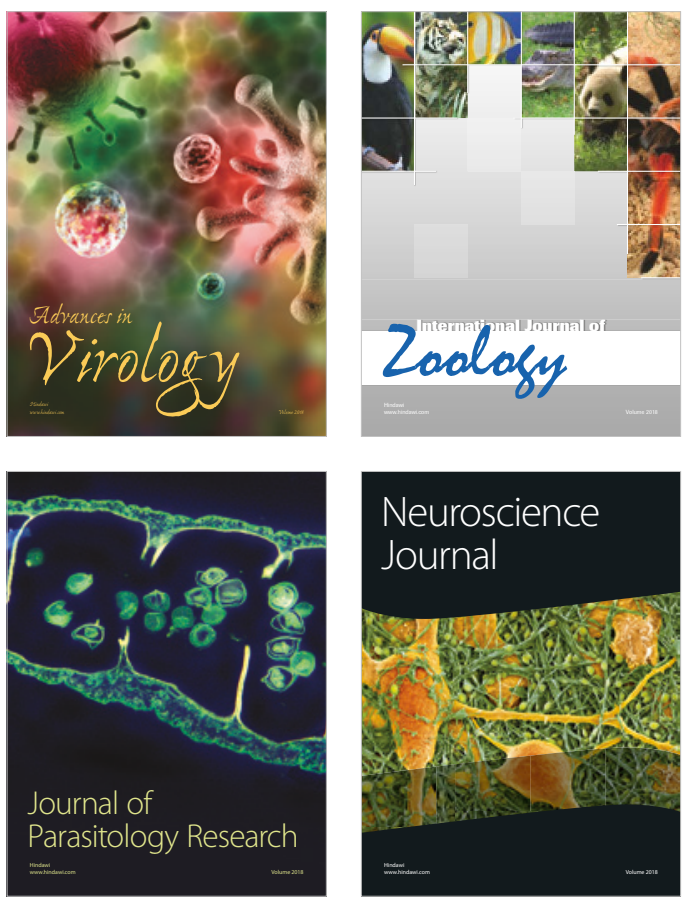
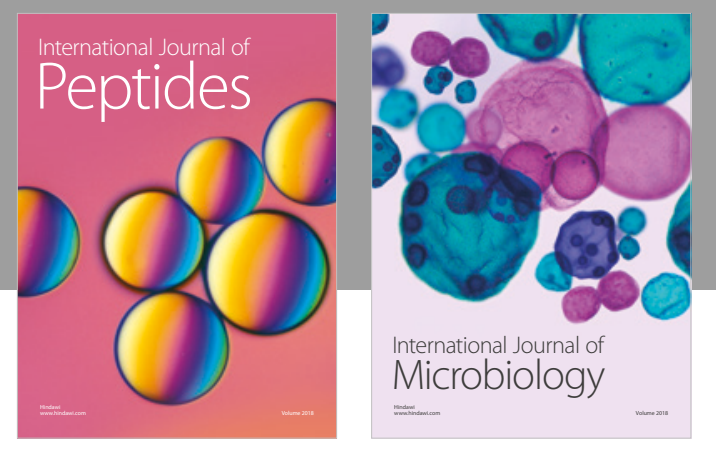

nternational Journal of Microbiology
Journal of
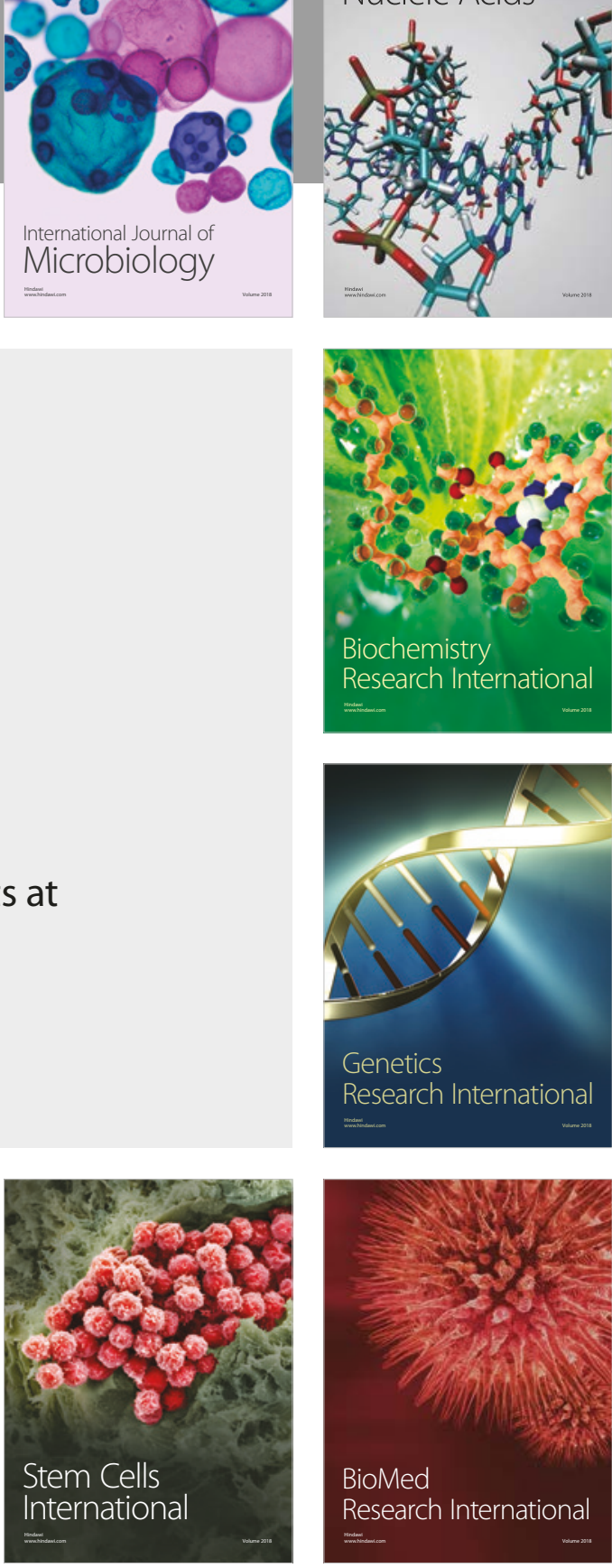
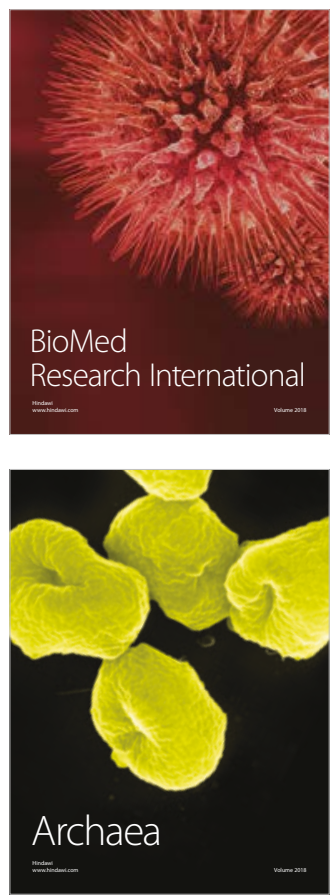